Article

\title{
The Identification of Iran's Moisture Sources Using a Lagrangian Particle Dispersion Model
}

\author{
Mojtaba Heydarizad ${ }^{1}$, Ezzat Raeisi ${ }^{1}$, Rogert Sori ${ }^{2}$ and Luis Gimeno ${ }^{2, *}$ \\ 1 Department of Geology, Faculty of Sciences, Shiraz University, Shiraz 71946-84695, Iran; \\ mojtabaheydarizad@shirazu.ac.ir (M.H.); e_raeisi@yahoo.com (E.R.) \\ 2 Environmental Physics Laboratory (EphysLab), Facultad de Ciencias, Universidade de Vigo, \\ 32004 Ourense, Spain; rogert.sori@uvigo.es \\ * Correspondence: l.gimeno@uvigo.es
}

Received: 28 August 2018; Accepted: 11 October 2018; Published: 17 October 2018

check for updates

\begin{abstract}
Iran has faced many water shortage crises in the past. Iran's moisture sources for precipitation were identified by Lagrangian approach using the FLEXible PARTicle dispersion model (FLEXPART) v9.0 model. The results demonstrate that Iran receives its moisture from both continental and oceanic sources. During the wet season, moisture uptake from the Arabian Sea, the Persian Gulf, and the Mediterranean Sea is dominant, while during the dry season, the role of the Red Sea, the Caspian Sea, and the Persian Gulf is intensified. Studying drought conditions by comparing 1-month, 6-month, and 12-month standardized precipitation index (SPI) with (E-P) values of oceanic and continental moisture sources (E stands for the evaporation and $\mathrm{P}$ the precipitation) using multiregression model demonstrates that among oceanic sources the Arabian Sea, the Persian Gulf, the Mediterranean Sea, and the Indian Ocean affect SPI values and among continental sources, moisture from bare grounds and cultivated lands influences SPI values during wet season. However, no correlation exists between oceanic and continental (E-P) and SPI values during the dry season. The results obtained by this study can be used by meteorologists and hydrology scientists for future water management programmes in Iran.
\end{abstract}

Keywords: drought conditions; FLEXPART; Iran; Lagrangian analysis; SPI

\section{Introduction}

Almost all aspects of any society are controlled and affected by climate, as it dominantly influences agriculture, economy, transportation, telecommunication, air pollution, and even political relations between countries. During the last half century, the world has faced intense changes in climate the impact of which can be seen in global average precipitation and temperature variations leading to large floods or droughts in different parts of the world. According to recent analyses, the global dry areas have increased $1.74 \%$ per decade since 1950 [1] mainly in highly populated semi-arid regions in the Middle East, Africa, and the south of the USA. Although climate change is hot scientific topic and many investigations have been done in this subject, its influence on components of water cycle particularly precipitation needs further investigations. According to a past paper [2], among the many challenges related to the hydrological cycle, those concerned with the atmospheric transport of moisture must receive special attention because of their importance within the atmospheric sciences. The moisture for precipitation is mainly provided by local evaporation or is transported by the wind from other regions [3]. The moisture responsible for heavy and moderate precipitations in semi-arid and arid regions is mainly transported into the region and is not related to local evaporation [4]. Three principle methods are normally used for the identification of moisture sources: numerical water vapour tracers, analytical or box models, and physical water vapour tracers (isotopes) [5]. Although it is obvious that 
analytical and numerical models are powerful tools for atmospheric investigations, they should be validated by physical methods.

Iran is located in the southwest of Asia with an area of 1,648,195 $\mathrm{km}^{2}$ and is limited between latitudes $25^{\circ} \mathrm{N}$ to $40^{\circ} \mathrm{N}$ and longitudes $44^{\circ} \mathrm{E}$ to $64^{\circ} \mathrm{E}$. Iran's topography is very complicated as two large mountain ranges (the Alborz mountain range with maximum elevation of $5670 \mathrm{~m}$ on Damavand's peak extending in the east-west direction and the Zagros mountain range with maximum elevation of 4409 m on Dena's peak extending in the north-west and south-east directions) border two large deserts of Dasht-e Lut and Dasht-e Kavir in central Iran. Iran is bordered by three large waterbodies: the Persian Gulf (with $1400 \mathrm{~km}$ length of coastline), the Oman Sea (with $637 \mathrm{~km}$ length of coastline) in the south, and the Caspian Sea (with $922 \mathrm{~km}$ length of coastline) in the north (Figure 1). Alborz and Zagros mountain ranges influence Iran's climatology dominantly, as they prevent air masses from bringing moisture toward the internal part of Iran plateau (central Iran) which results in low amounts of annual precipitation in central Iran [6]. Iran is located in a semi-arid and arid part of the world with an annual precipitation average of $252 \mathrm{~mm}$. For the purpose of this study we distinguish two seasons: wet (November to April) and dry (May to October), based on previous climatological studies in Iran [7-9]. Iran's weather is influenced by various air masses arrive from the north, west, southwest, and southeast directions. Siberian cold continental air mass (known as (cP) air mass) enters from the north and is blocked by the Alborz mountain range causing huge precipitation (more than $1300 \mathrm{~mm}$ per year) along the coastal area of the Caspian Sea and the northern slope of the Alborz mountain range. This air mass brings moisture from the Caspian Sea to Iran. The Sudan air mass influences the south and southwest of Iran and mainly brings moisture from the Arabian Sea, the Red Sea, the Persian Gulf, and the Oman Sea [6]. Occasionally, Sudan air mass merges with the Mediterranean system and causes heavy rainfalls and floods in the south and southwest of Iran [10]. The systems which influence the western and northwestern parts of Iran are the Mediterranean, north Atlantic, and Black Sea cyclones which are rich in humidity and have a dominant role in the precipitation and cloudiness of this region $[6,10]$. In addition to the mentioned systems which influence Iran during the wet season, Iran is also influenced by the Indian summer monsoon from the southeast direction which brings warm humid air, strong winds, and heavy rainfalls during the dry season [10]. Iran's spatial and temporal precipitation distribution is variable due to its vast area, large latitude variations, complex topography, large nearby waterbodies and various humidity sources, and air masses influencing it [7]. The maximum annual precipitation occurs in the west coast of the Caspian Sea (over $1300 \mathrm{~mm}$ ) and to a lower extent in some parts of Zagros mountain range $(\sim 700 \mathrm{~mm})$ [10], while the lowest amount of precipitation occurs in the centre and southeast of Iran (less than $100 \mathrm{~mm}$ ) [11]. Numerous studies have been done on spatial and temporal variations of precipitation in Iran including $[6,7,9,12-17]$. But few of these studies $[6,18]$ focus on the moisture sources of Iran's precipitation due to the complexity of moisture sources identification, the lack of precise equipment and monitoring systems, and reliable sets of data.

During the last few decades, new types of models such as HYSPLIT (U.S. National Atmospheric and Oceanic Administration (NOAA) Air resources Laboratory (ARL), Maryland, USA) and FLEXPART (Norsk Institutt for luftforskning (NILU), Norway) which consider climatological parameters on a daily or even hourly basis have improved climatological studies of the hydrological cycle dominantly.

FLEXPART v9.0 developed previously $[19,20]$ is a Lagrangian Particle Dispersion Model. The main advantage of using FLEXPART is its robustness to obtain the budget of (E-P) along air parcel trajectories tracked backward and forward in time and numerous and successful projects have been implemented by this method in the Sahel region [21], Iceland [22], Orinoco river basin [23], Central Brazil [24], Central America [25], China [26], the Danub River Basin [27], and the Niger River Basin [28]. In this study, the goal is to identify Iran's sources of moisture during the dry (May to October) and wet (November to April) seasons and to calculate the moisture uptake from these sources. Achieving this goal enables us to determine and investigate Iran's main seasonal sources of moisture. Likewise, the correlations 
between the (E-P) values of continental and oceanic moisture sources with Standard Precipitation Index (SPI) of 1, 6, and 12 months have been studied using multicomponent regression models.
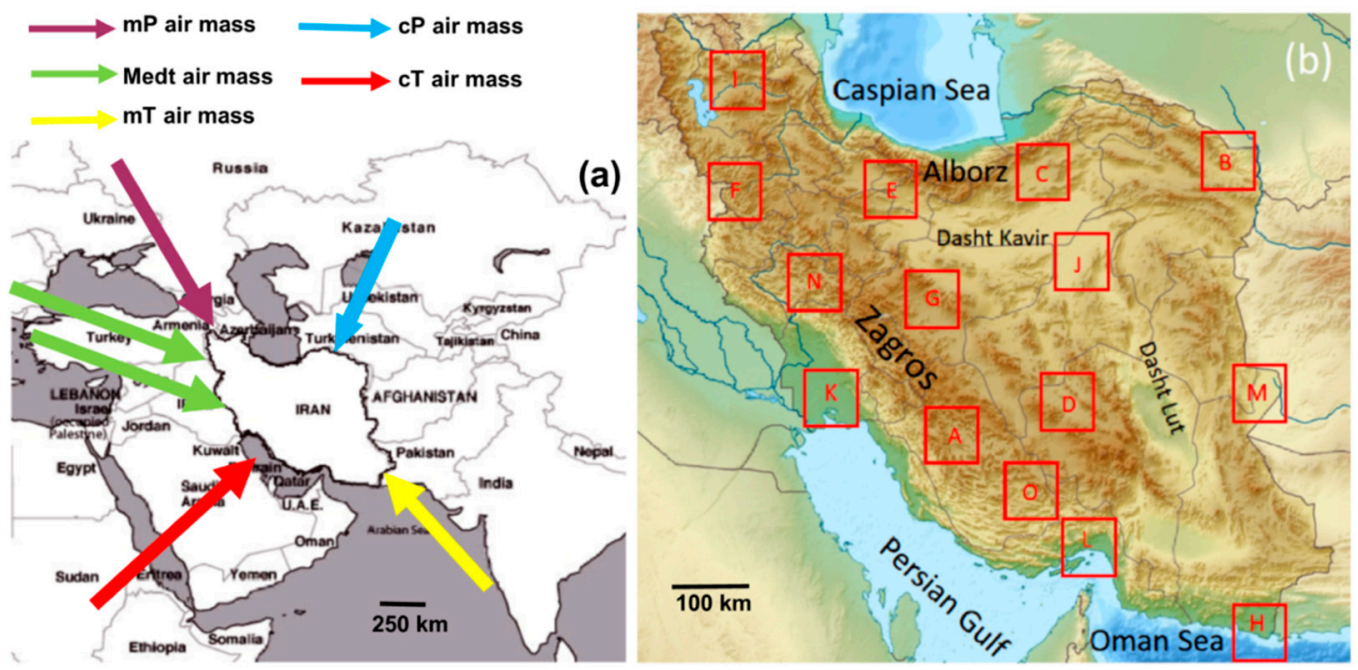

Figure 1. (a) Air masses influencing Iran and (b) spatial distribution of the 15 studied locations. (Shiraz (A), Mashhad (B), Shahrood (C), Rafsanjan (D), Hashtgerd (E), Marivan (F), Isfahan (G), Chabahar (H), Tabriz (I), Tabas (J), Ahvaz (K), Bandar Abbas (L), Zabol (M), Khoram Abad (N), and Darab (O)).

\section{Materials and Methods}

In this study, the FLEXible PARTicle dispersion model (FLEXPART) v9.0 model $[19,20]$ has been used to track 10 days backward in time (the average residence time of water vapour in the atmosphere [29]) the air particles residing over Iran and also over 15 studied locations of Shiraz, Mashhad, Shahrood, Rafsanjan, Hashtgerd, Marivan, Isfahan, Chabahar, Tabriz, Tabas, Ahvaz, Bandar Abbas, Zabol, Khoram Abad, and Darab with $1^{\circ}$ in longitude and latitude over Iran during the dry and wet season in period from 1981 to 2015 (Figure 1).

As input data to run FLEXPART model we used ERA-Interim reanalysis datasets from the European Centre for Medium-Range Weather Forecast (ECMWF) [30] at a $1^{\circ}$ horizontal resolution on 61 vertical levels from 0.1 to $1000 \mathrm{hPa}$. In a global experiment, FLEXPART v9.0 divides the atmosphere into approximately 2,000,000 uniformly distributed particles with the same mass, and then moving these particles with time through a 3-dimensional wind field (two horizontal dimensions and one vertical dimension) [31-33]. Along the trajectories, for each parcel the evaporation is $e$ and the precipitation is $p$. The balance of evaporation $(e)$ minus precipitation $(p)$ is calculated considering the changes of specific humidity $(q)$ in each air particle within time $(t)$, keeping constant the mass of the parcels, which is described by Equation (1):

$$
(e-p)=m(d q / d t)
$$

The summation of $(e-p)$ values of all particles in the atmospheric column over an area results in the net fresh water flux (E-P) of the related particles, where (E) represents evaporation and (P) represents precipitation per unit area. Along the backward trajectories, the $(\mathrm{E}-\mathrm{P})>0$ values indicate regions where evaporation exceeds precipitation, allowing one to identify where the air masses gain their moisture. On the contrary, $(\mathrm{E}-\mathrm{P})<0$ values demonstrate regions where precipitation dominates evaporation and are considered as moisture sinks $[19,20]$. As the aim of this study is to determine the moisture sources, only positive values of $(\mathrm{E}-\mathrm{P})$ have been considered. The (E-P) $>0$ values have been calculated for both continental and oceanic moisture sources. The moisture uptake from each oceanic sources has been calculated by masking each waterbodies area from the oceanic $(\mathrm{E}-\mathrm{P})>0$ map. Then, using each waterbody's (E-P) $>0$ map and amassing (e-p) for all the particles residing in 
the atmospheric column over an area, (E-P) values for each oceanic source have been calculated. As the locations of the continental moisture sources cover a vast area in both the dry and wet periods, the roles of each land use in providing moisture have been considered using a global land use map $(1 \times 1$ degree) from The Global Land Cover Facility [34]. For continental sources, calculating (E-P) values for each source has been the same as oceanic sources. The area of continental (E-P) $>0$ map has been masked from the global land use map. Then, using each land use (E-P) $>0$ map and adding (e-p) for all the particles in the atmospheric column over an area, continental (E-P) value for each land use has been determined.

Although this method has numerous advantages, it has some limitations as evaporation (E) and precipitation $(\mathrm{P})$ cannot be calculated separately and the quality of input data has a great influence on the reliability of the method. However, due to the large number of air particles in this method, it is hoped that the errors omit the effects of each other $[27,35]$.

Finally, the linear relationship between $(\mathrm{E}-\mathrm{P})>0$ values (oceanic and continental) and SPI values [36] at the time scales of 1,6 , and 12 months have also been investigated by a multiregression model. Precipitation data sets of Climatic Research Unit (CRU3.23TS) constructed from monthly precipitation data of global meteorological stations [37] were used to calculate SPI values for Iran. The negative SPI values indicate less than median precipitation in long-term precipitation time series and drought conditions, while positive SPI values indicate greater than median precipitation and wet conditions. If the amount of precipitation is null, it will cause non-normal distribution in data sets and distorted SPI values $[38,39]$. Two normality tests of Shapiro-Wilk and Kolmogorov-Smirnov have been carried out to determine the normality of data. Non-normal series were normalized using Johnson's transformation.

\section{Results and Discussion}

The climatological field of $(\mathrm{E}-\mathrm{P})>0$ obtained by the analysis of backward trajectories of air masses arriving over Iran for the wet and dry seasons from 1981 to 2015 (Figure 2a,b) shows the locations of the main moisture sources and spatial extension changes between the two seasons. Moisture uptake mainly occurs in the south, southwest, and west of Iran in the wet season (Figure 2a) and in the west and northeast in the dry season (Figure 2b). In Figure 2a,b, light blue line represents the $95 \%$ percentile (p95) of annual (E-P) $>0$ values; within the line are the $5 \%$ of grid points with the highest $(\mathrm{E}-\mathrm{P})>0$ values of the map which correspond to the (E-P) $>0$ values of $0.12 \mathrm{~mm} /$ day and $0.15 \mathrm{~mm} /$ day for the wet and dry seasons, respectively. Although choosing a contour line is arbitrary, it should not be so large as to include regions with minor effects on precipitation or so small as not to include regions which have a notable effect on precipitation $[28,35]$.

According to the threshold of $0.95 \%$ of $(\mathrm{E}-\mathrm{P})>0$ (Figure 2a,b), it can be observed that Iran receives moisture from different oceanic sources including the Persian Gulf, the Mediterranean Sea, the Black Sea, the Caspian Sea, the Oman Sea, the Red Sea, the Arabian Sea, and the Indian Ocean and also from continental sources. Studying the moisture sources in the seasonal scale shows that in the wet season the $(\mathrm{E}-\mathrm{P})>0$ pattern is more intense over the Red Sea, the Arabian Sea, the Mediterranean Sea, the Persian Gulf, and the Oman Sea (Figure 2a), while in the dry season, the roles of the Black Sea and the Indian Ocean increase and that of the Arabian Sea decreases (Figure 2b). In Figure 2a,b, the role of continental sources increases in the dry season compared to the wet season. Comparison of the obtained results with those of Vertically Integrated Moisture Flux (VIMF) for the period of 1980 to 2014 (Figure 2c,d) shows the most important regions of divergence (where evaporation exceeds precipitation). In the wet season, areas of divergence over the Arabian Sea, the Atlantic Ocean, the Persian Gulf, and the Oman Sea and to a lower extent the Indian Ocean are observed which is in accordance with moisture uptake sources during the wet season (Figure 2c). These moisture sources provide the main part of Iran's precipitation during the wet season. In the dry season, the huge divergence observed in the Indian Ocean which is responsible for Indian monsoon precipitations influences the southeast of Iran (Figure 2d). 

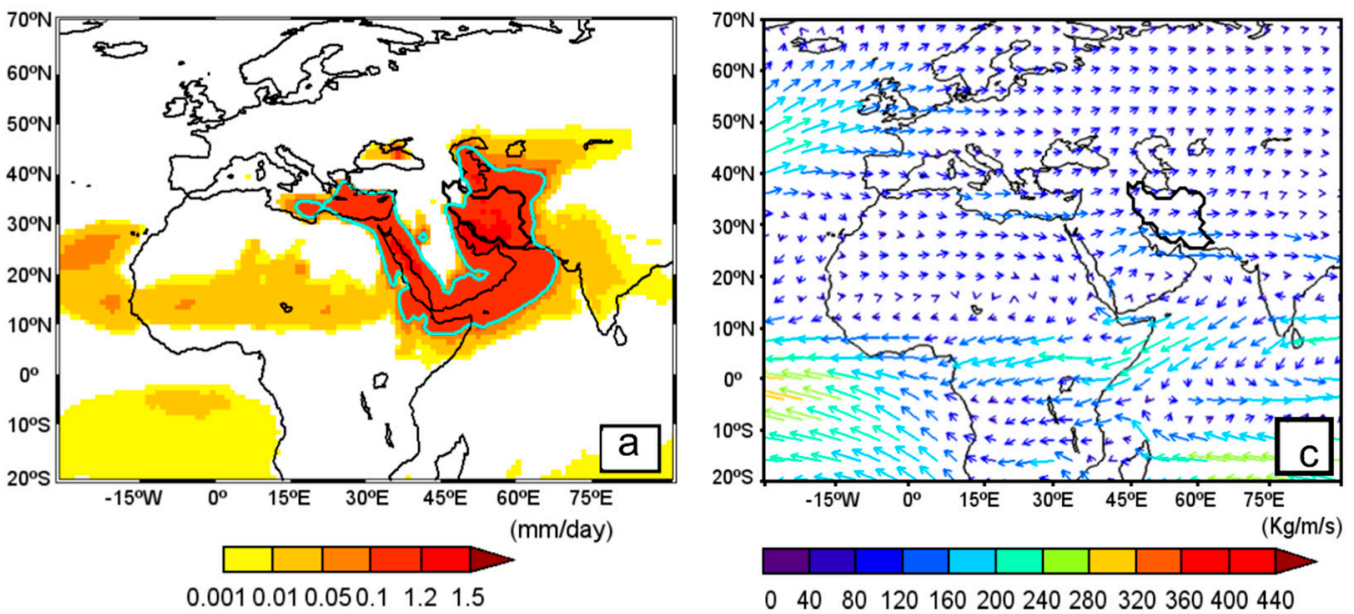

$(E-P)$
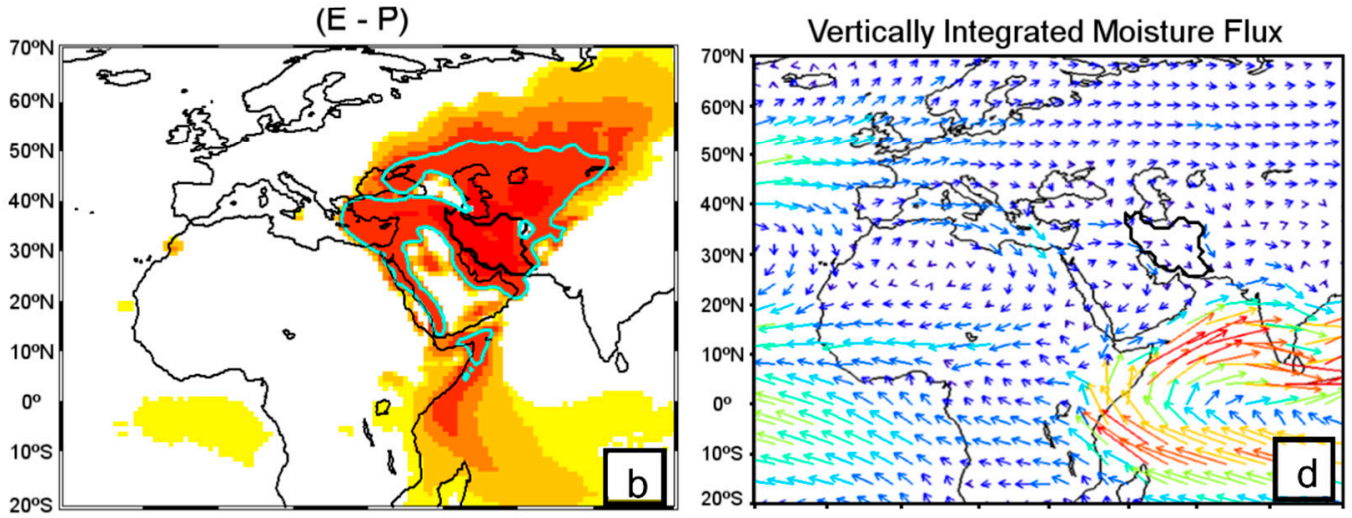

Figure 2. Seasonal pattern of $(\mathrm{E}-\mathrm{P})>0$ (mm/day) backward integrated from Iran along 10 days for wet (November to April) (a) and dry (May to October) (b) seasons. The light blue line (p95 value) shows the boundaries of the sources and vertically integrated moisture flux (vectors in $\mathrm{kg} \mathrm{m}^{-1} \mathrm{~s}^{-1}$ ) for wet (c) and dry (d) seasons (data obtained from ERA-Interim).

Studying continental and oceanic (E-P) values with precipitation amounts in the wet season demonstrates that in most cases precipitation increased when oceanic and continental (E-P) values increased and it decreased when oceanic and continental (E-P) values decreased (Figure 3a). In the dry season, continental (E-P) values increased intensively compare to wet season and no obvious correlation was observed between (E-P) values and precipitation amount (Figure 3b). During this season, the Earth's surface temperature increases intensively and stable atmospheric conditions dominate in Iran. These conditions prevent air uplifting mechanism and prevent precipitation from taking place. Low precipitation amounts in the dry season do not show a meaningful correlation with (E-P) values and are influenced by local parameters (Supplementary Figure S1).

To study more accurately the moisture sources influencing Iran, the (E-P) values have also been calculated for 15 locations of $1^{\circ}$ degree in longitude and latitude including Shiraz (A), Mashhad (B), Shahrood (C), Rafsanjan (D), Hashtgerd (E), Marivan (F), Isfahan (G), Chabahar (H), Tabriz (I), Tabas (J), Ahvaz (K), Bandar Abbas (L), Zabol (M), Khoram Abad (N), and Darab (O) for both wet (Figure 4) and dry seasons (Figure 5) and (Supplementary Table S1) from 1981 to 2015. 

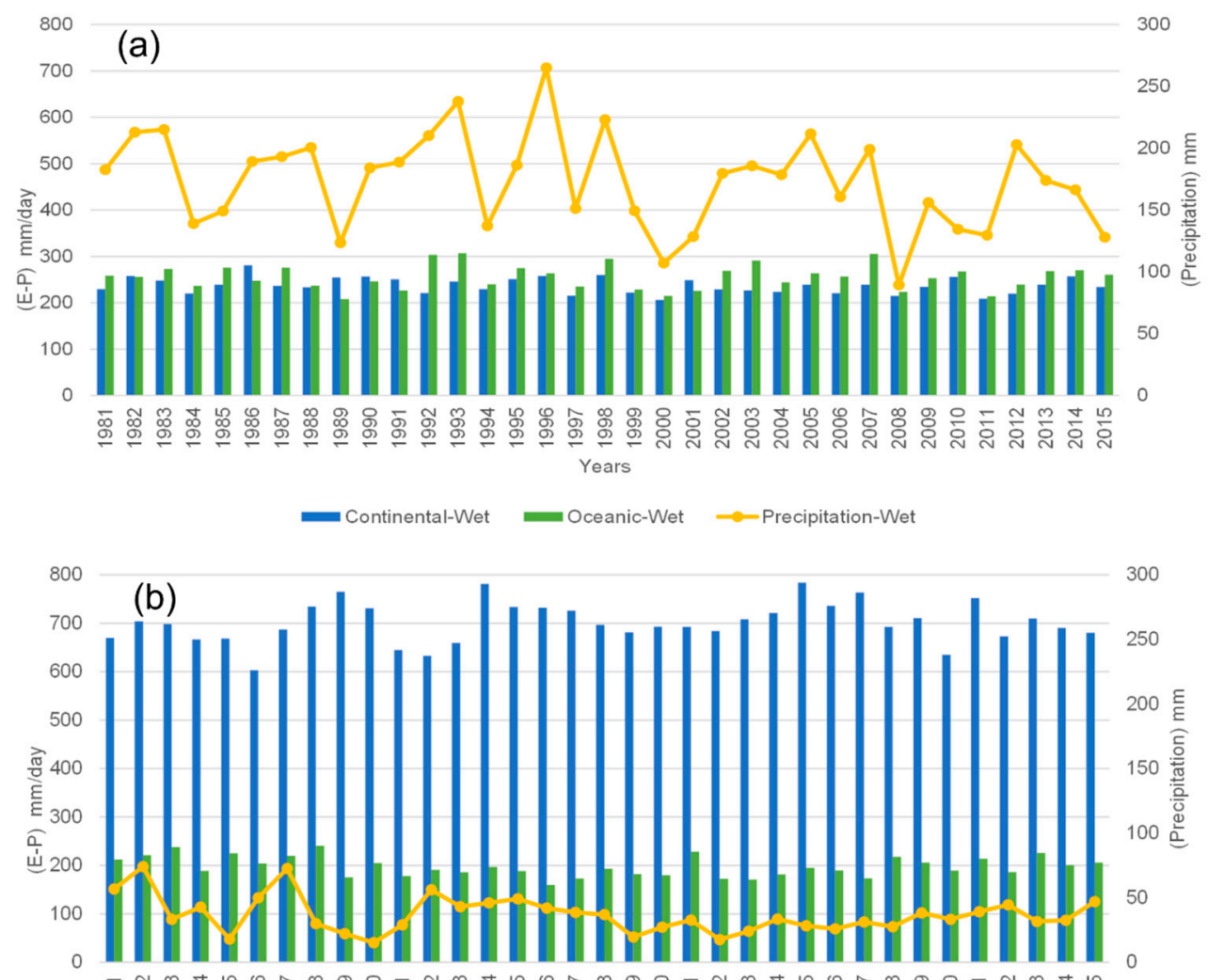

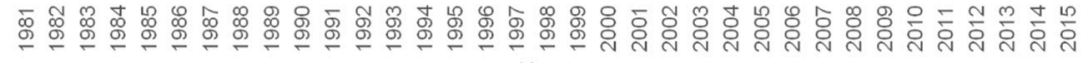

Continental-Dry $=$ Oceanic-Dry $\rightarrow$ Precipitation-Dry

Figure 3. Oceanic and continental (E-P) $>0$ (mm/day) values and precipitation amounts over Iran for the wet (a) and dry (b) seasons between 1981 and 2015.

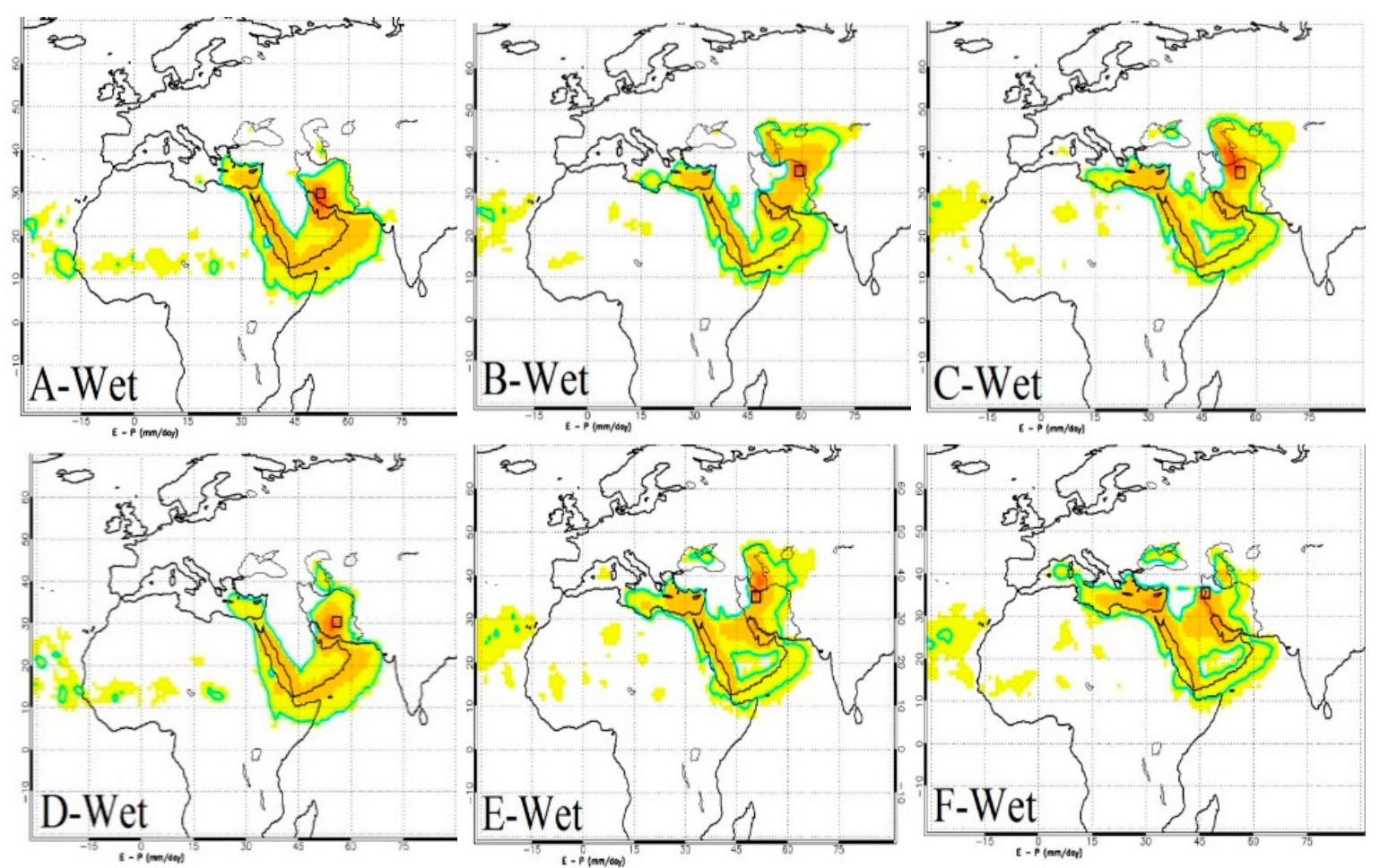

Figure 4. Cont. 

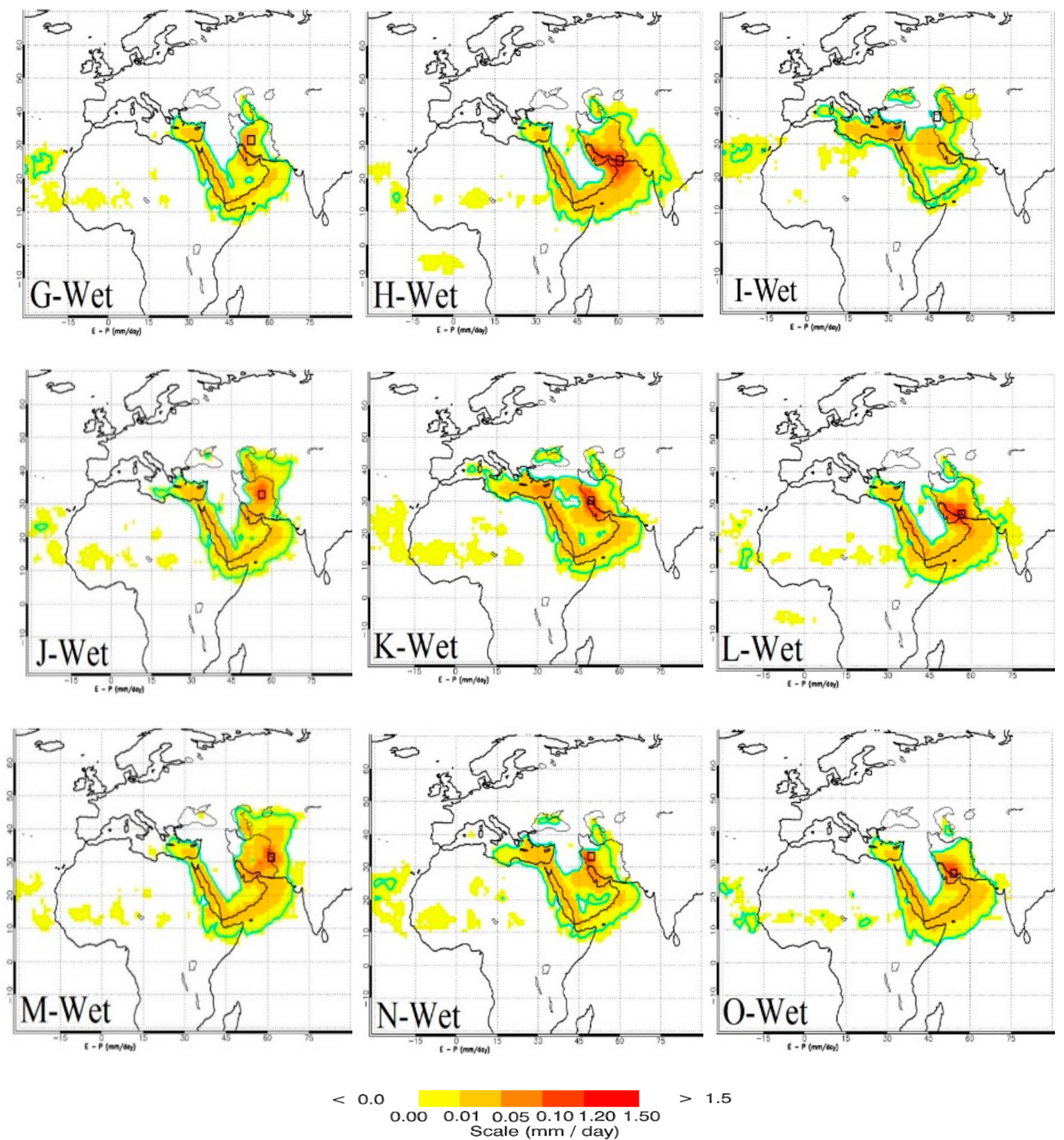

Figure 4. (E-P) backward models in 15 sub-regional locations (from (A-O)) for the wet season. The light green line shows the boundaries of 95 percentiles of $(\mathrm{E}-\mathrm{P})>0$. 

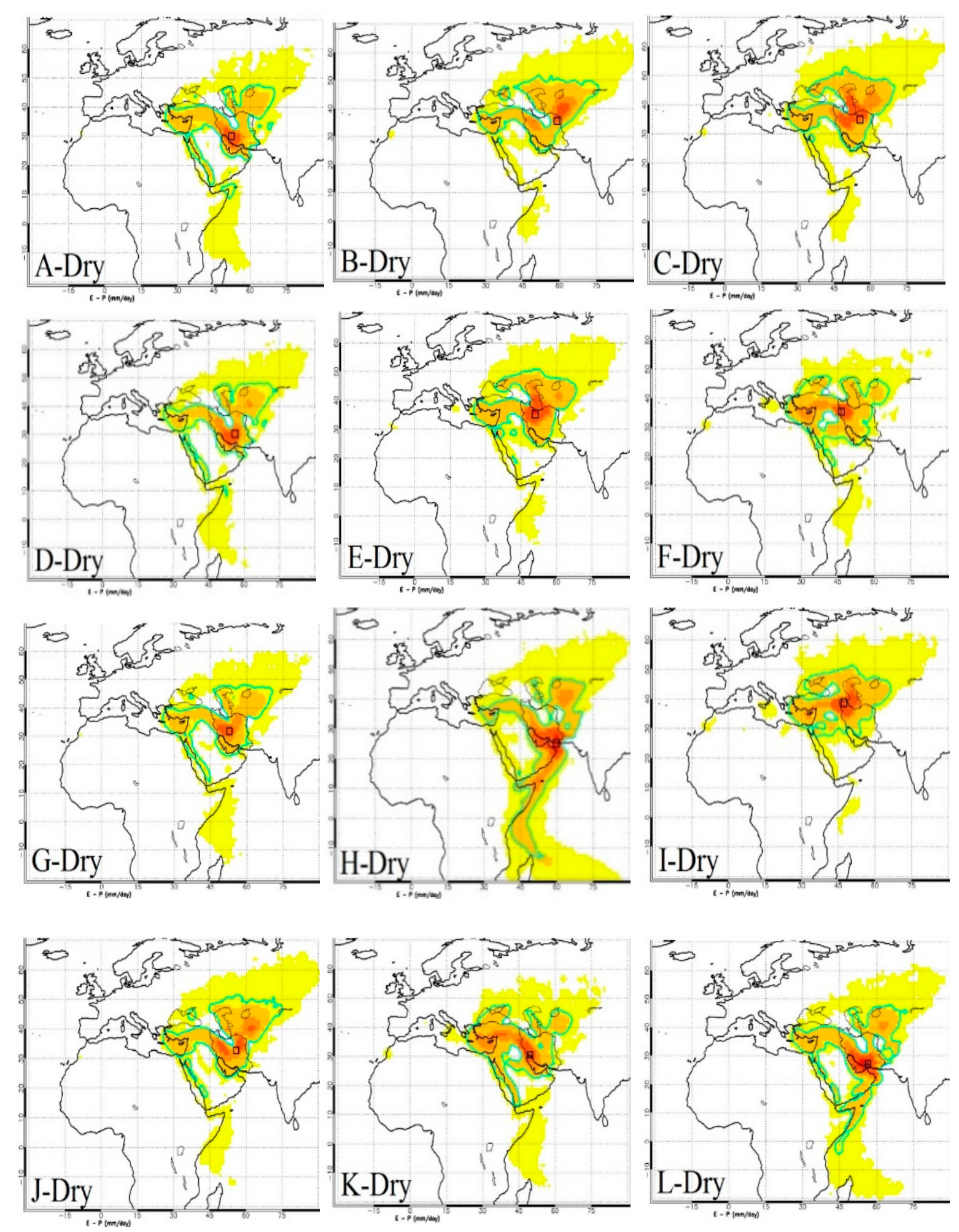

Figure 5. Cont. 


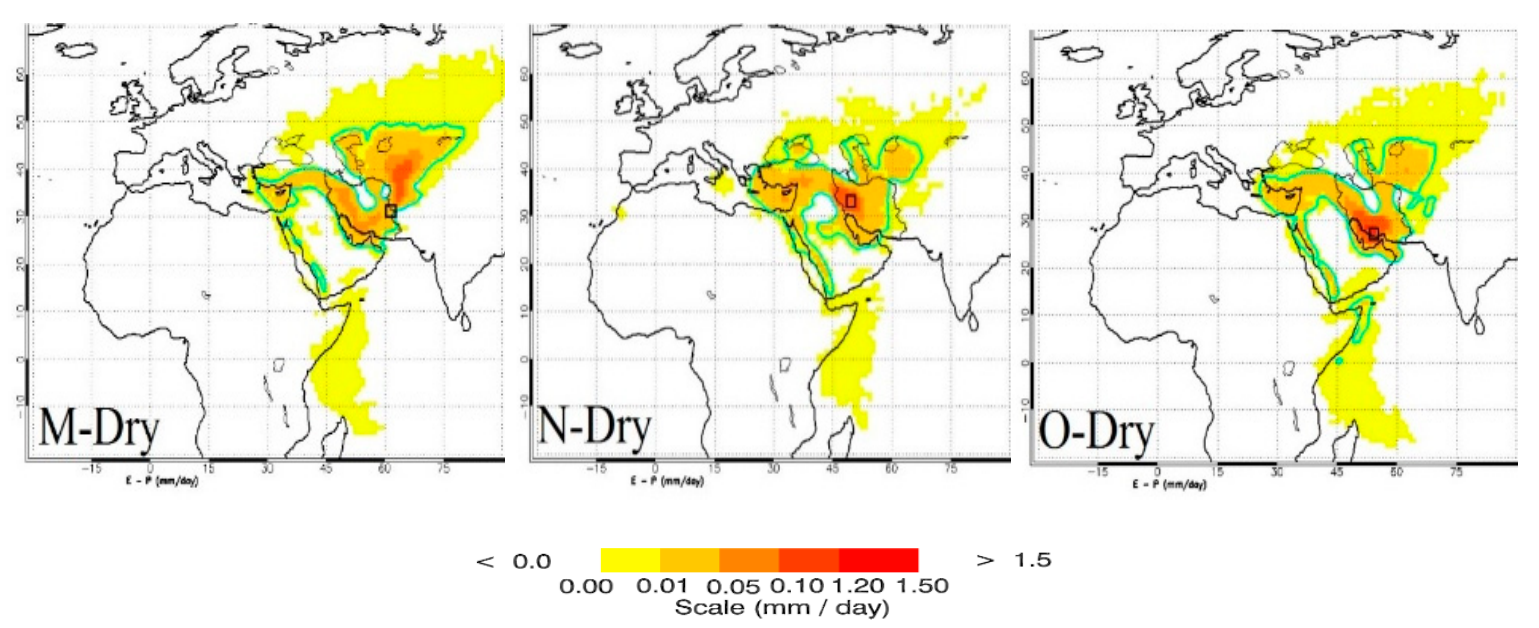

Figure 5. (E-P) backward models in 15 sub-regional locations (from (A-O)) for the dry season. The light green line shows the boundaries of 95 percentiles of $(\mathrm{E}-\mathrm{P})>0$.

For the air masses arriving over studied locations, the spatial distribution of moisture sources in the wet season is limited to the zone which covers the Red Sea, the Arabian Sea, the Persian Gulf, the Oman Sea, and the Mediterranean Sea. The studied locations in the western slope of Zagros mountain range including Shiraz (A), Marivan (F), Darab (O), and Khoram Abad (N) receive more precipitation compared to the studied locations in the eastern slope of Zagros mountain range including Rafsanjan (D) and Isfahan (G) due to the shadow effect of Zagros mountain range which prevents air masses and moisture from passing it most of the times. On the other hand, air masses bring higher latitude waterbodies moisture such as the Mediterranean Sea, the Black Sea, and the Caspian Sea are also blocked by Alborz mountains and only influence the locations in the north of Iran including Mashhad (B), Shahrood (C), Hashtgerd (E), and Tabriz (I). Tabas (J) and Zabol (M) studied locations near Iran's central deserts (Dasht-e Lut and Dasht-e Kavir) receive less precipitation compared to the other locations. Studied locations in the coastal areas of the Persian Gulf including Chabahar $(\mathrm{H})$, Bandar Abbas (L), and Ahvaz (K) have both the highest oceanic and continental (E-P) values but moderate precipitation amounts. In these locations, although oceanic and continental (E-P) values are high, the parameters responsible for precipitation are not strong and active enough. During the dry season, the roles of the Arabian Sea, the Red Sea, and the Oman Sea decrease, while the roles of the Black Sea, the Caspian Sea, and also continental sources intensify. Higher weather temperature in the dry season results in much higher continental (E-P) values than oceanic (E-P) values. Atmospheric stability which governs most parts of Iran prevents precipitation in most studied locations except for Tabriz (I), Marivan (F), Khoram Abad (N), Bandar Abbas (L), and Chabahar (H) (Figure 5 and Supplementary Table S1).

In stable atmospheric conditions, if an air parcel is lifted over a mountain or blown upward by an updraft, the lifted air will sink back down to the ground as this air parcel is cooler than air particles around it which prevents precipitation from taking place. Atmospheric stability is studied using the omega equation $\omega$ which is a partial differential equation for the vertical velocity Equation (2).

$$
\omega=d p / d t
$$

where $d / d t$ represents a material derivative. Negative values of $\omega$ correspond to ascending motion and instability, while positive $\omega$ values represent descending motion and stable atmospheric conditions [40]. Simultaneous studies of precipitation and $\omega$ values over Iran demonstrate that during the wet season the most negative $\omega$ values and atmospheric instability are observed over Zagros mountain range and the coastal areas of the Caspian Sea due to air parcel lifting mechanism over Zagros and Alborz mountain ranges. During the dry season, atmospheric stability dominates a large part of Iran which results in dry conditions although oceanic and continental E-P values are high. Atmospheric instability 
which exists in a small part of Iran in the west and northwest causes precipitation in Tabriz (I) and Marivan (F) studied locations due to local parameters. Atmospheric instability has also been observed in rare cases in the south and south-east of Iran due to the monsoon effect in Bandar Abbas (1) and Chabahar $(\mathrm{H})$ locations (Figure 6).
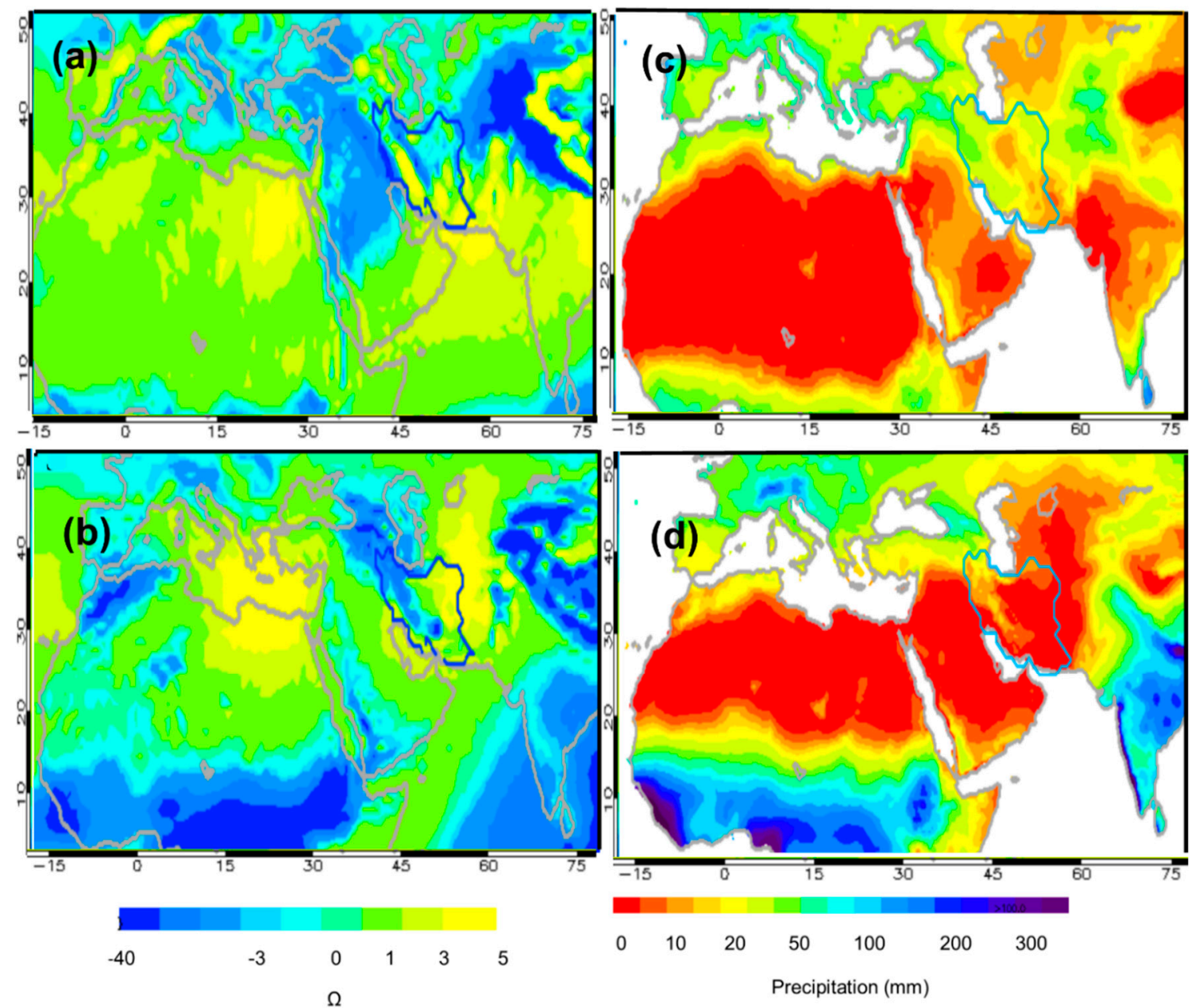

Figure 6. The stability of atmosphere (Omega $\omega$ ) variations $(\mathbf{a}, \mathbf{b})$ and precipitation distribution $(\mathbf{c}, \mathbf{d})$ over Iran and nearby regions for wet and dry seasons, respectively (1981-2015).

\subsection{The Contribution Rate of Continental and Oceanic Moisture Sources and Their Role in Moisture Uptake in} Wet and Dry Seasons

The oceanic and continental moisture uptake sources have been determined for the wet and dry seasons from 1981 to 2015 (Figure 7a,b).

The contribution percentage of oceanic and continental moisture sources in the dry and wet season is presented in Table 1 . The results are in agreement with some previous studies $[6,18]$ using old and traditional meteorological methods. Alijani [6] believed that the Mediterranean Sea is the dominant moisture source of Iran's precipitation. In contrast, Karimi and Farajzadeh [18] believed that the Arabian Sea with a share of 39\% and the Mediterranean Sea with a share of 38\% are the dominant providers of Iran's total moisture, while the Red Sea $(6.8 \%)$, the Oman Sea $(4.8 \%)$, the Caspian Sea $(4.4 \%)$, the Persian Gulf (3.7\%), and the Black Sea (3.3\%) have a minor contribution. 

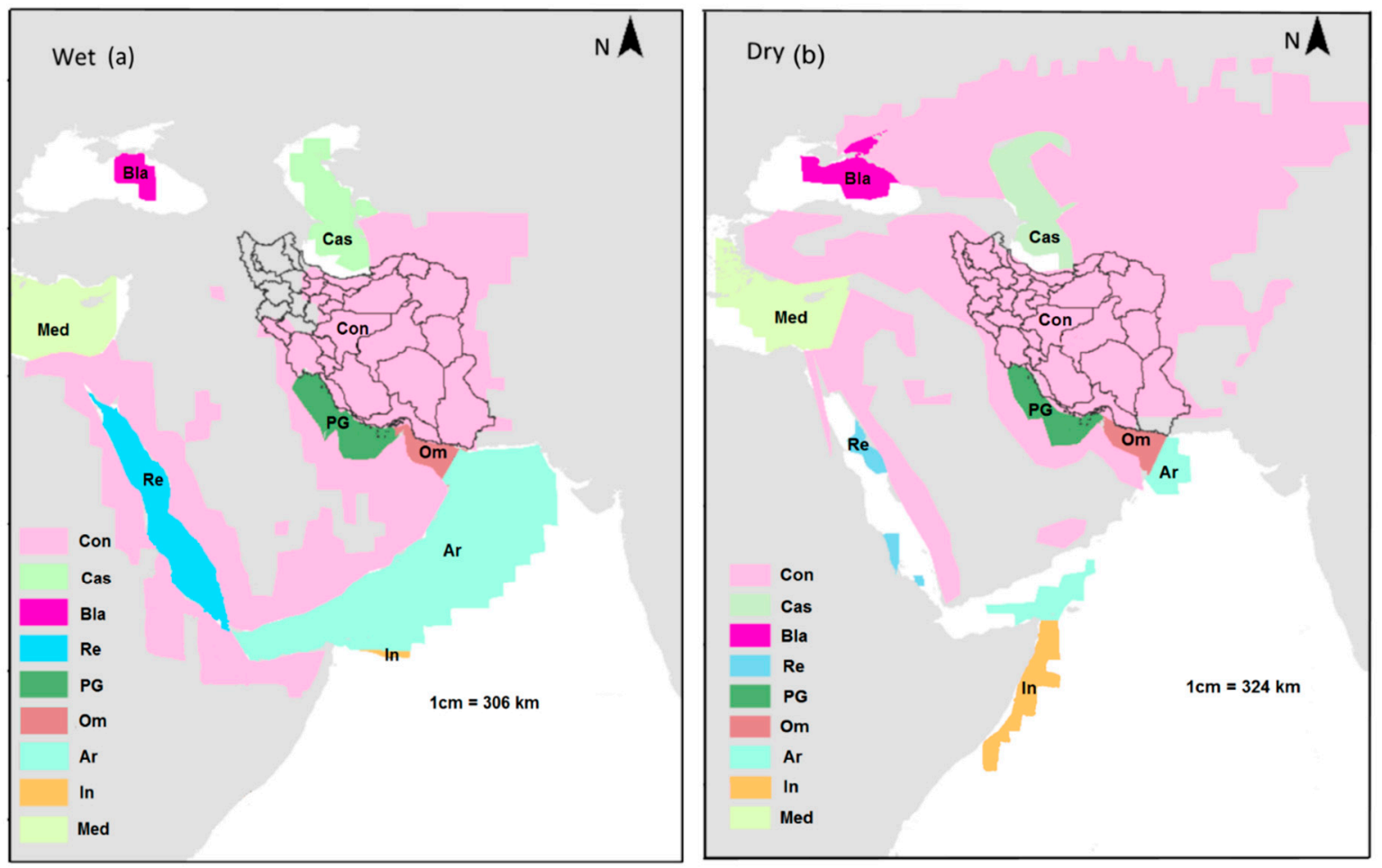

Figure 7. The spatial distribution of continental and oceanic moisture sources (E-P) $>0$ for Iran in the wet (a) and dry (b) seasons. Con stands for Continental, Cas stands for the Caspian Sea, Bla stands for the Black Sea, Re stands for th Red Sea, PG stands for the Persian Gulf, Om stands for the Oman Sea, Ar stands for the Arabian Sea, In stands for the Indian Ocean, and Med stands for the Mediterranean Sea.

Table 1. The moisture uptake percentage from various oceanic and continental sources for the Shiraz and Mashhad boxes during the wet and dry season from 1981 to 2015.

\begin{tabular}{|c|c|c|c|c|c|}
\hline \multirow{2}{*}{ Oceanic Sources } & \multicolumn{2}{|c|}{ Season } & \multirow{2}{*}{ Continental Sources } & \multicolumn{2}{|c|}{ Season } \\
\hline & Wet $(\%)$ & Dry (\%) & & Wet $(\%)$ & Dry (\%) \\
\hline The Arabian Sea & 28.33 & 1.5 & Bare grounds & 61.67 & 22.97 \\
\hline The Mediterranean Sea & 17.26 & 10.46 & Shrubs and bare grounds & 25.06 & 33.14 \\
\hline The Persian Gulf & 21.51 & 12.16 & Grass lands & 12.72 & 38.30 \\
\hline The Red Sea & 17.09 & 52.22 & Cultivated crops lands & 0.48 & 4.33 \\
\hline The Caspian Sea & 9.77 & 16.66 & Wooded grass lands & 0.06 & n.d. \\
\hline The Oman Sea & 5.47 & 4.41 & $\begin{array}{l}\text { Coniferous evergreen forests } \\
\text { and woodlands }\end{array}$ & n.d. & 1.04 \\
\hline The Black Sea & 0.31 & 1.88 & $\begin{array}{l}\text { Mixed coniferous forests and } \\
\text { woodlands }\end{array}$ & n.d. & 0.09 \\
\hline \multirow{2}{*}{ The Indian Ocean } & 0.23 & 0.67 & Wooded grasslands & n.d. & 0.08 \\
\hline & & & $\begin{array}{l}\text { Broadleaf deciduous forests and } \\
\text { woodlands }\end{array}$ & n.d. & 0.02 \\
\hline
\end{tabular}

In continental sources during the wet season, the higher moisture uptake from bare grounds is due to evaporation from snow surfaces and temporary lakes in bare grounds which are under the direct influence of sunlight. However during the dry season, grasslands are the dominant source of moisture, followed by shrubs and bare grounds, and bare grounds.

In addition to study the variations of moisture uptake ratios in the north and south parts of Iran, the moisture uptake from oceanic sources in Shiraz station (A) in the south of Iran and in Mashhad station (B) in the north of Iran has been studied (Figure 8). 


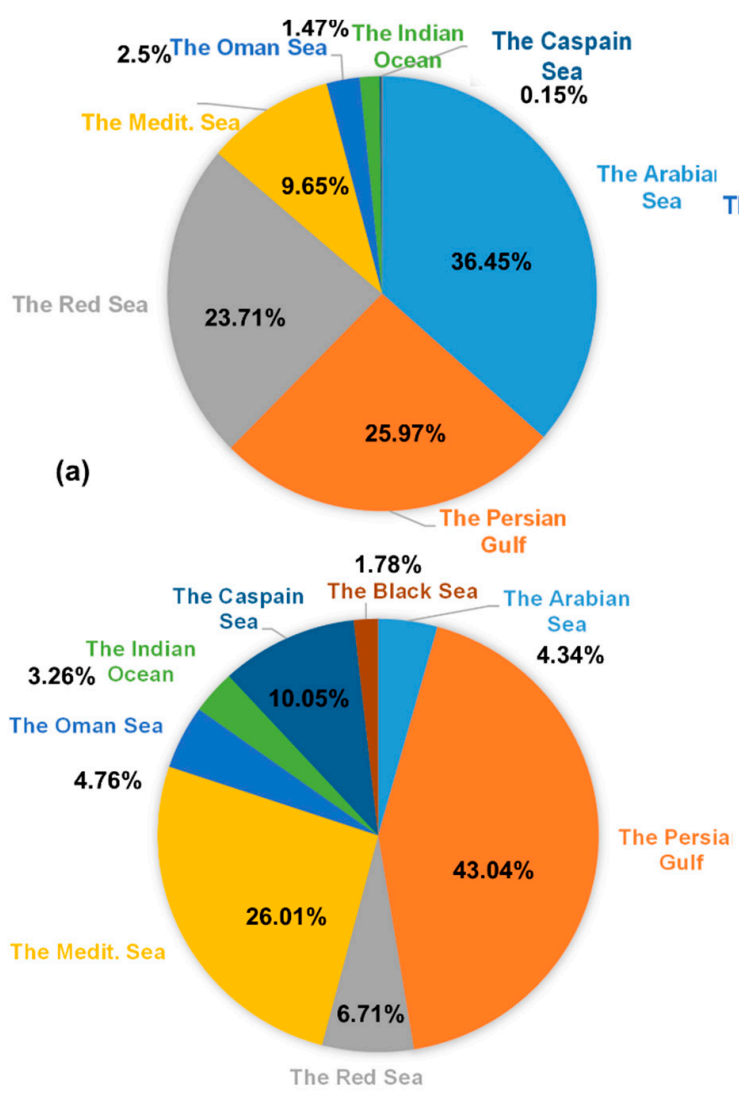

(c)

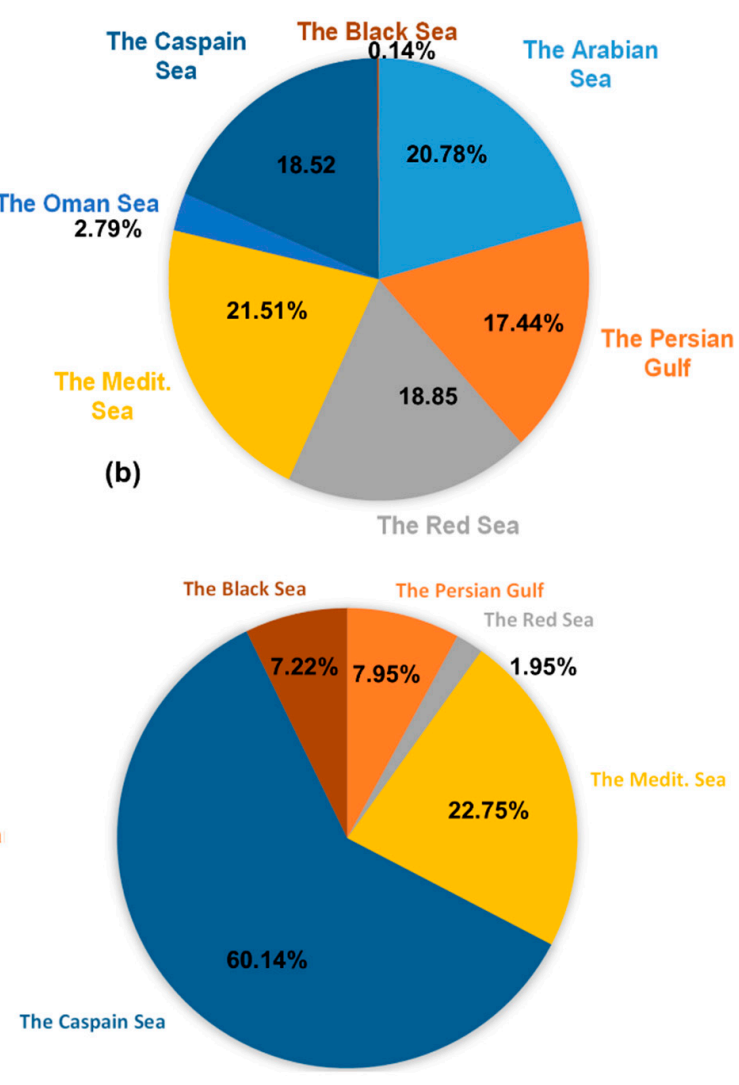

(d)

Figure 8. The moisture uptake ratios from various oceanic sources for the Shiraz $(\mathbf{a}, \mathbf{c})$ and Mashhad $(\mathbf{b}, \mathbf{d})$ locations during the wet and dry seasons, respectively.

During the wet season, strong air masses can transfer huge amounts of moisture mainly from low latitude waterbodies to most parts of Iran and cause notable precipitations. However, during the dry season, although moisture uptake from oceanic and continental sources is high this moisture cannot be transferred deeply to Iran plateau. This is due to the intense atmospheric stability of Iran plateau which prevents air masses from transferring moisture which in turn prevents precipitation and thus moisture only increases air moisture content in the regions near waterbodies.

\subsection{The Role of Continental and Oceanic Moisture Sources during Drought Conditions in Iran}

In the wet season during 2008, a large drought happened with the lowest precipitation amount of $89.3 \mathrm{~mm}$ and resulted in large negative values of $-1.24,-1.64$, and -0.61 for 1 -month, 6 -month, and 12-month SPIs. However, the maximum precipitation amount of $265 \mathrm{~mm}$ and humid conditions occurred in 1996 with positive values of 0.76 in 1-month, 0.87 in 6-month, and 1.27 in 12-month SPIs. During the dry season in 1990, precipitation was reduced to a minimum of $15.04 \mathrm{~mm}$ and 1-month, 6-month, and 12-month SPI values were $-1.085,-0.77$, and -0.14 , respectively, while in 1982 the maximum precipitation amount of $74.01 \mathrm{~mm}$ occurred and 1-month, 6-month, and 12-month SPI values were $0.7,1.41$, and 1.09, respectively (Supplementary spreadsheet S1).

In addition, SPI values for the two studied locations of Shiraz (A) and Mashhad (B) have also been calculated (using the precipitation data provided by Iran Meteorological Organization) to determine the differences that exist in the drought conditions of the locations in the north and south of Iran (Supplementary spreadsheet S1). Both of these locations demonstrated large variations in SPI values and precipitation amounts during the study period. This is due to the large continental effect in most parts of the country except for a small coastal area near the Caspian Sea. The continental effect results in large temperature variations between day and night and summer and winter measurements 
in most climatological locations especially deep inside the Iranian plateau. Although the dominant moisture sources for the wet season are the same for these two locations, the moisture sources in the dry season, dominant moisture uptake ratios, precipitation amount variations, and drought conditions are different in these two locations. This confirms the results of previous studies $[6,10,12,18]$ which emphasized climatological differences in different parts of Iran.

The correlations between oceanic and continental (E-P) values over Iran have been compared with 1 month, 6 months, and 12 months SPI values. To study the simultaneous effect of oceanic (including the Arabian Sea, the Black Sea, the Caspian Sea, the Indian Ocean, the Mediterranean Sea, the Oman Sea, and the Persian Gulf) and continental moisture sources on drought conditions, their (E-P) values on 1,6 , and 12 months SPI values have been correlated using multiregression models. In the model developed for the 1-month SPI in the wet season, only the Arabian Sea, the Indian Ocean, and the Persian Gulf have a direct influence on SPI values (sig < 0.05). In the 6-month SPI model, the Arabian Sea and the Mediterranean Sea and for the 12-month SPI model only the Arabian Sea influence SPI values (Supplementary Table S2).

The Arabian Sea, which has a dominant role in providing moisture for Iran, also has a crucial influence on SPI values and drought conditions. However, the Persian Gulf and the Mediterranean Sea which are the second and the third dominant moisture sources of Iran's precipitation only influence 1-month and 6-month SPI values. Other moisture sources such as the Red Sea, the Caspian Sea, the Oman Sea, and the Black Sea do not have a direct influence on SPI values and drought conditions according to developed regression models (Sig > 0.05). On the other hand, although the Indian Ocean has a very weak contribution in providing Iran's moisture affects 1-month SPI values. Because the main moisture sources influencing drought conditions in Iran, i.e., the Arabian Sea, the Red Sea, the Persian Gulf, and even the Indian Ocean are located in the south of Iran and north of Africa, any meteorological changes in this area may have a great influence on Iran's precipitation variations.

In continental moisture sources, moisture originating from bare grounds only influences 1-month and 6-month SPI values, while moisture coming from cultivated crop lands influences 12-month SPI values. Moisture originating from other land uses has no influence on the developed regression models (Sig $>0.05)$. In the dry season, although high values of $(\mathrm{E}-\mathrm{P})>0$ were observed in both continental and oceanic moisture sources, the developed models demonstrated no correlation between (E-P) and SPI values (Supplementary Table S2). This is because atmospheric stability influences large parts of Iran and prevents precipitation from taking place, while rare precipitation events are caused by local parameters.

\section{Conclusions}

The results obtained by the FLEXPART Model demonstrate that Iran receives its moisture from various oceanic and continental moisture sources. In the wet season, the Arabian Sea and bare grounds and during the dry season the Red Sea and grasslands, are the main oceanic and continental moisture sources. Studying drought conditions by comparing 1-month, 6-month, and 12-month SPI values with (E-P) values in oceanic and continental moisture sources using multiregression models shows that among the oceanic sources the Arabian Sea, the Mediterranean Sea, the Persian Gulf, and the Indian Ocean influence SPI values, while bare grounds and cultivated lands are the dominant continental moisture sources influencing SPI values. During the dry season, no correlation between (E-P) values and SPI values was observed in any oceanic and continental moisture sources. This is due to the fact that atmospheric stability dominates most parts of the country and precipitation takes place due to local and rare parameters during the dry season. In Mashhad station (north of Iran) and Shiraz station (south of Iran), meaningful variations in dominant moisture sources were observed in the dry season, while meaningful variations were observed in moisture uptake ratios, precipitation variations, and drought conditions in both dry and wet seasons. This demonstrates the variations of climatology in the north and south of Iran and is in agreement with previous studies [6,18]. 
Supplementary Materials: The following is available online at http://www.mdpi.com/2073-4433/9/10/408/s1. Table S1: The continental and oceanic (E-P) values, precipitation amounts, and 1-month, 6-month, and 12-month SPI values calculated for 15 studied locations. Shiraz (A), Mashhad (B), Shahrood (C), Rafsanjan (D), Hashtgerd (E), Marivan (F), Isfahan (G), Chabahar (H), Tabriz (I), Tabas (J), Ahvaz (K), Bandar Abbas (L), Zabol (M), and Khoram Abad (N); Table S2: Regression model of the (E-P) $>0$ values of continental and oceanic moisture sources with 1-month, 6-month, and 12-month SPI values; Figure S1: The correlation between oceanic and continental (E-P) $>0$ values vs. precipitation amount in Iran during dry and wet seasons; Spreadsheet S1: The full data set of average precipitation amount, and 1-month, 6-month, and 12-month SPI values calculated for Iran, Shiraz, and Mashhad locations for dry and wet seasons during 1981 to 2015.

Author Contributions: Conceptualization, E.R.; Data curation, L.G.; Formal analysis, R.S.; Investigation, M.H.; Methodology, M.H.; Project administration, E.R. and L.G.; Resources, L.G.; Software, R.S.; Supervision, E.R.; Writing-original draft, M.H.

Acknowledgments: We thank our colleagues in Environmental Physics Laboratory (EPhysLab) of Vigo University in Orense Campus Spain and Shiraz University in Iran who kindly helped us to complete the research.

Conflicts of Interest: The authors declare no conflict of interest.

\section{References}

1. Dai, A.; Trenberth, K.E.; Qian, T. A Global Dataset of Palmer Drought Severity Index for 1870-2002: Relationship with Soil Moisture and Effects of Surface Warming. J. Hydrometeorol. 2004, 5, 1117-1130. [CrossRef]

2. Gimeno, L. Grand challenges in atmospheric science. Front. Earth Sci. 2013, 1, 1. [CrossRef]

3. Trenberth, K. Short-Term Climate Variations: Recent Accomplishments and Issues for Future Progress. Bull. Am. Meteorol. Soc. 1997, 78, 1081-1096. [CrossRef]

4. Barati, G.R.; Heydari, I. Classification of Iran western Precipitation. In The first Iran National Climate Change Conference; Iran Meteorological Organization: Tehran, Iran, 2003; pp. 16-23.

5. Gimeno, L.; Stohl, A.; Trigo, R.M.; Dominguez, F.; Yoshimura, K.; Yu, L.; Drumond, A.; Durán-Quesada, A.M.; Nieto, R. Oceanic and terrestrial sources of continental precipitation. Rev. Geophys. 2012, 50. [CrossRef]

6. Alijani, B. Iran Climatology, 5th ed.; Payam Nour Publication: Tehran, Iran, 2000; ISBN 978-964-455-621-0.

7. Modarres, R.; Sarhadi, A. Rainfall trends analysis of Iran in the last half of the twentieth century. J. Geophys. Res. Atmos. 2009, 114, 101. [CrossRef]

8. Pourasghar, F.; Tozuka, T.; Jahanbakhsh, S.; Sari Sarraf, B.; Ghaemi, H.; Yamagata, T. The interannual precipitation variability in the southern part of Iran as linked to large-scale climate modes. Clim. Dyn. 2012, 39, 2329-2341. [CrossRef]

9. Balling, R.C.; Sadegh Keikhosravi Kiany, M.; Roy, S.; Khoshhal, J. Trends in Extreme Precipitation Indices in Iran: 1951-2007. Adv. Meteorol. 2016, 1-8. [CrossRef]

10. Sabziparvar, A.A.; Movahedi, S.; Asakereh, H.; Maryanaji, Z.; Masoodian, S.A. Geographical factors affecting variability of precipitation regime in Iran. Theor. Appl. Climatol. 2015, 120, 367-376. [CrossRef]

11. Darand, M.; Mansouri Daneshvar, M.R. Regionalization of Precipitation Regimes in Iran Using Principal Component Analysis and Hierarchical Clustering Analysis. Environ. Process. 2014, 1, 517-532. [CrossRef]

12. Rahimzadeh, F.; Asgari, A.; Fattahi, E. Variability of extreme temperature and precipitation in Iran during recent decades. Int. J. Climatol. 2009, 29, 329-343. [CrossRef]

13. Tabari, H.; Talaee, P.H. Temporal variability of precipitation over Iran: 1966-2005. J. Hydrol. 2011, 396, 313-320. [CrossRef]

14. Ghesmati, D.; Shafti, L.; Kompouti, Z.; Naghusi, A.; Pepki, M.; Zarif, O.; Haghighat, M. Spatial Variation of Precipitation in Iran. J. Soil Water Sci. 2004, 1, 16-25.

15. Rousta, I.; Soltani, M.; Zhou, W.; Cheung, H. Analysis of extreme precipitation events over central plateau of Iran. Am. J. Clim. Chang. 2016, 5, 297. [CrossRef]

16. Ghalhari, G.A.F.; Roudbari, A.A.D.; Asadi, M. Erratum to: Identifying the spatial and temporal distribution characteristics of precipitation in Iran. Arab. J. Geosci. 2016, 9, 629. [CrossRef]

17. Javari, M. Trend and Homogeneity Analysis of Precipitation in Iran. Climate 2016, 4, 44. [CrossRef]

18. Karimi, M.; Farajzadeh, M. Spatial and Temporal distribution of Iran's precipitation moisture. J. Geogr. Sci. Stud. 2011, 19, 109-127.

19. Stohl, A.; James, P.; Stohl, A.; James, P. A Lagrangian Analysis of the Atmospheric Branch of the Global Water Cycle. Part II: Moisture Transports between Earth's Ocean Basins and River Catchments. J. Hydrometeorol. 2005, 6, 961-984. [CrossRef] 
20. Stohl, A.; James, P. Lagrangian Analysis of the Atmospheric Branch of the Global Water Cycle. Part I: Method Description, Validation, and Demonstration for the August 2002 Flooding in Central Europe. J. Hydrometeor 2004, 5, 656-678. [CrossRef]

21. Nieto, R.; Gimeno, L.; Trigo, R.M. A Lagrangian identification of major sources of Sahel moisture. Geophys. Res. Lett. 2006, 33, L18707. [CrossRef]

22. Nieto, R.; Gimeno, L.; Gallego, D.; Trigo, R. Contributions to the moisture budget of airmasses over Iceland. Meteorol. Zeitschrift 2007, 16, 37-44. [CrossRef]

23. Nieto, R.; Gallego, D.; Trigo, R.; Ribera, P.; Gimeno, L. Dynamic identification of moisture sources in the Orinoco basin in equatorial South America. Hydrol. Sci. J. 2008, 53, 602-617. [CrossRef]

24. Drumond, A.; Nieto, R.; Gimeno, L.; Ambrizzi, T. A Lagrangian identification of major sources of moisture over Central Brazil and La Plata Basin. J. Geophys. Res. Atmos. 2008, 113. [CrossRef]

25. Durán-Quesada, A.M.; Gimeno, L.; Amador, J.A.; Nieto, R. Moisture sources for Central America: Identification of moisture sources using a Lagrangian analysis technique. J. Geophys. Res. Atmos. 2010, 115, 103. [CrossRef]

26. Drumond, A.; Nieto, R.; Gimeno, L. Sources of moisture for China and their variations during drier and wetter conditions in 2000-2004: A Lagrangian approach. Clim. Res. 2011, 50, 215-225. [CrossRef]

27. Ciric, D.; Stojanovic, M.; Drumond, A.; Nieto, R.; Gimeno, L. Tracking the Origin of Moisture over the Danube River Basin Using a Lagrangian Approach. Atmosphere 2016, 7, 162. [CrossRef]

28. Sorí, R.; Nieto, R.; Drumond, A.; Gimeno, L. The Niger River Basin Moisture Sources: A Lagrangian Analysis. Atmosphere 2017, 8, 38. [CrossRef]

29. Numaguti, A. Origin and recycling processes of precipitating water over the Eurasian continent: Experiments using an atmospheric general circulation model. J. Geophys. Res. Atmos. 1999, 104, 1957-1972. [CrossRef]

30. Dee, D.P.; Uppala, S.M.; Simmons, A.J.; Berrisford, P.; Poli, P.; Kobayashi, S.; Andrae, U.; Balmaseda, M.A.; Balsamo, G.; Bauer, P.; et al. The ERA-Interim reanalysis: Configuration and performance of the data assimilation system. Q. J. R. Meteorol. Soc. 2011, 137, 553-597. [CrossRef]

31. Ciric, D.; Nieto, R.; Ramos, A.M.; Drumond, A.; Gimeno, L. Contribution of Moisture fromMediterranean Sea to Extreme Precipitation Events over Danube River Basin. Water 2018, 10, 1182. [CrossRef]

32. Sori, R.; Nieto, R.; Vicente-Serrano, S.M.; Drumond, A.; Gimeno, L. A Lagrangian perspective of the hydrological cycle in the Congo River basin. Earth Syst. Dyn. 2017, 8, 653-675. [CrossRef]

33. Drumond, A.; Taboada, E.; Nieto, R.; Gimeno, L.; Vicente-Serrano, S.M.; Ignacio López-Moreno, J. Lagrangian analysis of the present-day sources of moisture for major ice-core sites. Earth Syst. Dyn. 2016, 7, 549-558. [CrossRef]

34. (GLCF), T.G.L.C.F. Available online: www.landcover.org (accessed on 10 July 2018).

35. Drumond, A.; Marengo, J.; Ambrizzi, T.; Nieto, R.; Moreira, L.; Gimeno, L. The role of the Amazon Basin moisture in the atmospheric branch of the hydrological cycle: A Lagrangian analysis. Hydrol. Earth Syst. Sci. 2014, 18, 2577-2598. [CrossRef]

36. Mckee, T.B.; Doesken, N.J.; Kleist, J. The relationship of drought frequency and duration to time scales. In The IX Conference on Applied Climatology; American Meteorological Society: Boston, MA, USA, 1993; pp. 179-184.

37. Harris, I.; Jones, P.D.; Osborn, T.J.; Lister, D.H. Updated high-resolution grids of monthly climatic observations-The CRU TS3.10 Dataset. Int. J. Climatol. 2014, 34, 623-642. [CrossRef]

38. Wu, H.; Svoboda, M.D.; Hayes, M.J.; Wilhite, D.A.; Wen, F. Appropriate application of the standardized precipitation index in arid locations and dry seasons. Int. J. Climatol. 2007, 27, 65-79. [CrossRef]

39. Naresh Kumar, M.; Murthy, C.S.; Sesha Sai, M.V.R.; Roy, P.S. On the use of Standardized Precipitation Index (SPI) for drought intensity assessment. Meteorol. Appl. 2009, 16, 381-389. [CrossRef]

40. Holton, J.R. An Introduction to Dynamic Meteorology; Dmowska, R., Holton, J.R., Thomasrossbay, H., Eds.; ElsevierAcademic Press: San Diego, CA, USA, 2004; ISBN 0-12-354015-1.

(C) 2018 by the authors. Licensee MDPI, Basel, Switzerland. This article is an open access article distributed under the terms and conditions of the Creative Commons Attribution (CC BY) license (http:/ / creativecommons.org/licenses/by/4.0/). 